\title{
EVALUATION OF PHYTOCHEMICAL SCREENING AND ANTIMICROBIAL ACTIVITIES OF ETHANOLIC EXTRACTS OF LEAVES AND BARK OF ARDISIA COLORATA
}

\author{
Easin Syed*, Benyamin Mashroor, Fouad Md. Delwar Hossain, Natik Bi-Illah, Dr. Rajib
} Bhattacharjee, Dr. JMA Hannan

Department of Pharmacy, North South University, Bashundhara, Baridhara, Dhaka 1229, Bangladesh

\section{Authors' Contributions}

The work was carried out by the equal contribution of all of the authors. All authors read and approved the final manuscript.

\begin{abstract}
The Ardisia colorata is one of the rare hill-tract plants in Bangladesh. The experimental research was intended to evaluate the phytochemical and antimicrobial activity of $70 \%$ ethanolic extract of leaves and bark of Ardisia colorata. Preliminary phytochemical screening of both the leaf and bark extract revealed the presence of various classes of compounds such as saponins, reducing sugars, tannins, and terpenoids with minor presence of alkaloid and flavonoid. When antimicrobial study was carried out against 10 different strains of microorganisms by detecting the zone of inhibition with disc diffusion technique, the two extracts showed very strong effect especially against Vibrio parahemolyticus and Bacillus subtilis with trace activity against Salmonella typhi. When further quantitative estimation was carried out using Minimum Inhibitory Concentration (MIC) with alternate methodology involving incorporation of phenol red indicator, their corresponding MIC numerical values were deduced at $3 \mathrm{mg} / \mathrm{ml}$ respectively.
\end{abstract}

Keywords: Ardisia colorata, Myrsinaceae, Phytochemical screening, Antimicrobial activity, Disc Diffusion Technique, Minimum Inhibitory Concentrations (MIC).

\section{Introduction}

The plants have been a rich source of medicines because they produce wide array of bioactive molecules, most of which probably evolved as chemical defense against predation or infection. It is estimated that only one percent of 2,65,000 flowering plants on earth have been studied exhaustively for their chemical composition and potential against important medicinal value ${ }^{[1]}$. In many developing countries, traditional medicine is one of the primary healthcare systems ${ }^{[2]}$. Herbs are widely exploited in the traditional medicine and their curative potentials are well documented.

\footnotetext{
${ }^{*}$ Correspondence to author:

Easin Syed

Ka-96/1, Kuril Kazi Bari

Vatara, Dhaka-1229

Bangladesh.

Tel No: +8801726312574

E-mail: esie345@yahoo.com
} 
Large scale evaluation of the local flora exploited in traditional medicine for various biological activities is a necessary first step in the isolation and characterization of the active principle and further leading to drug development. Nearly $50 \%$ of drugs used in medicine are of plant origin, and only a small fraction of plants with medicinal activity has been assayed. There is therefore much current research devoted to the phytochemical investigation of higher plants which have ethnobotanical information associated with them. The phytochemicals isolated are then screened for different types of biological activities ${ }^{[3]}$.

Ardisia colorata ROXB. is a tree or shrub from Myrsinaceae family. It is used as folk medicine for liver disease, cough and diarrhea in Thailand[4]. The leaves are alternate or pseudo-verticillate, usually punctate or punctate-lineate. The calyx is campanulate or cupular; sepals are free or barely united at base, imbricate or quincuncial, usually punctate or punctate-lineate.

\section{Materials and Methods}

\section{Collection of Plant and Preparation of Dry Powder}

Fresh bark and leaves of Ardisia colorata was collected from Moulivibazar, Sylhet, Bangladesh. The whole plant was collected cleaned, sun-dried and finally grinded to the desired reduced size feasible to carry out the next extraction process. The plant was identified by the renowned taxonomists at Bangladesh National Herbarium, Mirpur, Dhaka. The DAB accession no. for $A$. colorata was 35589 respectively).

\section{Preparation of Plant Extract}

The sample was kept under sunshade for 5 days then they were heated through oven to be fully dried at below $40^{\circ} \mathrm{C}$ for 24 hours. After drying the sample, it was grinded thoroughly to powder form. This powder was stored in cold conditions in an airtight container. The powdered obtained was extracted via the method of cold extraction using $70 \%$ ethanol and kept for a period of 3 days accompanying occasional shaking and stirring. The extracts were filtered (using Whatman filter paper) and the filtrates were concentrated to dryness using a rotary evaporator (Bibby RE-200, Sterilin Ltd., UK) at $68^{\circ} \mathrm{C}$ at reduced pressure, to form $70 \%$ ethanolic extracts. The dried crude extracts were kept at $-4^{\circ} \mathrm{C}$ and protected from light. It rendered a gummy concentrate of reddish black color. The gummy concentrate was designated as crude extract. Then the crude extract was dried by freeze drier and preserved at $4^{\circ} \mathrm{C}^{[5]}$.

\section{Phytochemical Screening}

Qualitative phytochemical tests for the identification of alkaloids, flavonoids, steroids, gum and carbohydrates, saponins, tannins, reducing sugars and terpenoids were carried out for the extracts by the method described by Harborne and Sazada et al[6,7]. The freshly prepared extract of Ardisia colorata were used qualitatively tested for the presence of chemical constituents. Phytochemical screening of the extract was performed using the following reagents and chemicals: Alkaloids with Wagner reagent, flavonoids with the use of concentrated $\mathrm{HCl}$, tannins with $5 \%$, and saponins with ability to produce suds. Gum was tested using Molisch reagents and concentrated sulfuric acid, steroids with sulfuric acid, reducing sugar with the use ó-napthol and sulfuric acid and terpenoids with chloroform and concentrated $\mathrm{HCl}$. Previous phytochemical investigation of $A$. colorata resulted in the confirmation of rapanone and ilexo[[8]. 


\section{Antimicrobial Test}

\section{Disc Diffusion Test}

The antimicrobial activity for both extracts was determined by the disc diffusion method ${ }^{[0]}$. Both gram positive and gram-negative bacterial strains were used for the test. Solutions of known concentration $(\mathrm{mg} / \mathrm{ml})$ of the test samples were prepared. Dry and sterilized filter paper discs (6 mm diameter) were impregnated with known amounts of the test substances using micropipette. Discs containing the test material were placed on nutrient agar medium uniformly seeded with the test microorganisms. Standard antibiotic discs (Kanamycin $30 \mu \mathrm{g} / \mathrm{disc}$ ) and blank discs (impregnated with solvents) were used as a positive and negative control. These plates were then kept at low temperature $\left(4^{\circ} \mathrm{C}\right)$ for $24 \mathrm{~h}$ to allow maximum diffusion. The plates were then incubated at $37^{\circ} \mathrm{C}$ for $24 \mathrm{~h}$ to allow maximum growth of the organisms. The test materials having antibacterial activity inhibited the growth of the microorganisms and a clear, distinct zone of inhibition was visualized surrounding the medium. After incubation, the growth inhibition rings were quantified by measuring the diameter for the zone of inhibition in millimeters. All assays were carried out twice.

\section{Minimum Inhibitory Concentration (MIC)}

The minimum inhibitory concentration of the plant extract was determined by a method which involves incorporation of indicators ${ }^{[10]}$. In this case, 3 bacterial strains (Salmonella typhi, Vibrio parahemolyticus and Bacillus subtilis) were selected to test the minimum inhibitory concentration of the plant extract in which higher zones of inhibition was exhibited. The selected bacterial strains were allowed to grow in Mueller-Hinton Broth medium containing $10 \%$ glucose and $0.5 \%$ phenol red in it. The solutions of glucose and phenol red were prepared by heating at $110^{\circ} \mathrm{C}$ for 10 mins. The bacterial strains were previously prepared in nutrient broth medium and were kept in the incubator for 24 hours. Then after dilution, the bacterial strains were put into the Mueller-Hinton Broth medium containing $10 \%$ glucose and $0.5 \%$ phenol red in several test tubes ( 8 test tubes for each bacterium). In each cases there were 3 control groups ( $\mathrm{C} 1$ containing only the growth medium, $\mathrm{C} 2$ containing the bacterium and the growth medium which was kept in the refrigerator and C3 containing bacterium and the growth medium which was kept in the incubator). In the other 5 test tubes, the test samples were added in various concentrations ( $1 \mathrm{mg}, 2 \mathrm{mg}, 3 \mathrm{mg}, 4 \mathrm{mg}$ and $5 \mathrm{mg}$ ).

Then after keeping all the test tubes in the incubator for 12 hours, the growth of bacteria was indicated by the change in color of the solution from red to yellow. The concentration at which no color change occurs indicates inhibition of bacterial growth. So the minimum concentration of test sample at which no color change occurred was observed to determine the minimum inhibitory concentration in each of the three cases.

\section{Results and Discussion}

The result of the phytochemical investigation of the ethanol extract of Ardisia colorata bark indicates the presence of alkaloids, tannins, flavonoids, saponins, gums and carbohydrates, steroids, terpenoids. Results of ethanol extract of Ardisia colorata leaves indicates the presence of alkaloids, tannins, flavonoids, saponins, gums and carbohydrates, steroids, terpenoids.

Flavonoids, a large group of naturally occurring plant phenolic compounds including flavones, flavonols, isoflavones, flavonones and chalcones, also known as nature's tender 
drugs, possess numerous biological/pharmacological activities. Recent reports of antiviral, anti-fungal, antioxidant, anti-inflammatory, antiallergenic, antithrombic, anticarcenogenic, hepatoprotective, and cytotoxic activities of flavonoids have generated interest in studies of flavonoid-containing plants. Of these biological activities, the anti-inflammatory capacity of flavonoids has long been utilized in Chinese medicine and the cosmetic industry as a form of

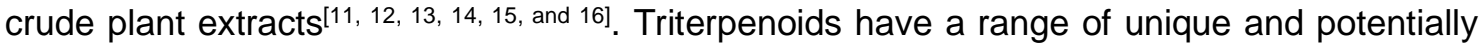
usable biological effects and reference to the use of plants with high saponin/triterpenoid content can be found in the first written herbarium. Triterpenoids are studied for their antiinflammatory, hepatoprotective, analgesic, antimicrobial, antimycotic, virostatic, immunomodulatory and tonic effects. They are used in the prevention and treatment of hepatitis, parasitic and protozoal infections and for their cytostatic effects. The disadvantage of using triterpenoids is the toxicity associated with their hemolytic and cytostatic properties. Hand in hand with ongoing extraction and isolation of natural products therefore, is the development of synthetic derivatives with lower toxic and higher therapeutic potential.

Table 1: The table shows the different tests that were performed and its corresponding indication of the presence of phytochemical constituent of our extracts

\begin{tabular}{|c|c|c|c|}
\hline \multirow{2}{*}{$\begin{array}{c}\text { Phytochemical } \\
\text { Constituents }\end{array}$} & \multirow{2}{*}{ Tests } & \multicolumn{2}{|c|}{ Presence (+/-) } \\
\cline { 3 - 4 } & Wagner's & $\begin{array}{c}\text { Ardisia colorata } \\
\text { (Bark) }\end{array}$ & $\begin{array}{c}\text { Ardisia colorata } \\
\text { (Leaves) }\end{array}$ \\
\hline \multirow{2}{*}{ Alkaloids } & Mayer's & + & + \\
\hline Tannins & Ferric Chloride Test & - & - \\
\hline Flavonoids & & +++ & ++ \\
\hline Saponins & Frothing Test & +++ & + \\
\cline { 2 - 4 } & Olive Oil Test & ++ & - \\
\hline Gums and & Molisch Test & +++ & + \\
\cline { 2 - 4 } Carbohydrates & Barfoed's Test & - & +++ \\
\hline Reducing Sugar & & +++ & +++ \\
\hline Steroids & & +++ & +++ \\
\hline Terpinoids & & +++ & - \\
\hline Glycosides & Keller-Kiliani Test & - & ++ \\
\hline
\end{tabular}

[Symbol (+++) indicates present in high concentration, Symbol (++) indicates present in moderate concentration, Symbol (+) indicates present in trace concentration (-) and indicates possible absence of photochemical constituent.]

In the second part, qualitative antimicrobial test was conducted using the disc diffusion technique. Here the ethanolic extracts of Ardisia colorata bark and Ardisia colorata leaves, were tested against 10 pathogenic bacterial strains. Some of these ethanolic extracts exhibited significant antimicrobial activity against some of the test microorganisms while other extracts did not. The zones of inhibition produced by Ardisia colorata (bark) extract against almost all microorganisms except Sarcina lutea and Escherichia coli were found to be more than $7 \mathrm{~mm}$. This Ardisia colorata (bark) extract showed no effects against these microorganisms. Among all test organisms/strains, Ardisia colorata (bark) exhibited more significant zone of inhibition to Salmonella typhi and Bacillus subtilis with comparatively less for Vibrio parahemolyticus. The zones of inhibition produced by Ardisia colorata (leaves) extract against almost all microorganisms except Salmonella paratyphi and Escherichia coli were found to be more than $7 \mathrm{~mm}$. This Ardisia colorata leaves extract showed no effects 
against these microorganisms. Among all test organisms/strains, Ardisia colorata (leaves) exhibited more significant zone of inhibition to Bacillus subtilis and Vibrio parahemolyticus with comparatively less for Salmonella typhi.

Table 2: Results of antibacterial activity represented by zone of inhibition of sample extracts and standard antibiotic by Diffusion Disc Methodology

\begin{tabular}{|l|c|c|c|c|c|}
\hline \multicolumn{1}{|c|}{ Test Organisms } & $\begin{array}{c}\text { Standard } \\
\text { Disc }\end{array}$ & $\begin{array}{c}\text { Ardisia } \\
\text { colorata } \\
\text { bark } \\
\mathbf{( 1 0 \mu l )}\end{array}$ & $\begin{array}{c}\text { Ardisia } \\
\text { colorata } \\
\text { bark } \\
\mathbf{( 2 0 \mu l )}\end{array}$ & $\begin{array}{c}\text { Ardisia } \\
\text { colorata } \\
\text { leaves } \\
(\mathbf{1 0 \mu l )}\end{array}$ & $\begin{array}{c}\text { Ardisia } \\
\text { colorata } \\
\text { leaves } \\
\mathbf{( 2 0 \mu l )}\end{array}$ \\
\hline 1. Bacillus cereus & $30 \mathrm{~mm}$ & $7 \mathrm{~mm}$ & $8 \mathrm{~mm}$ & $9 \mathrm{~mm}$ & $9 \mathrm{~mm}$ \\
\hline 2. Bacillus subtilis & $30 \mathrm{~mm}$ & $8 \mathrm{~mm}$ & $11 \mathrm{~mm}$ & $8 \mathrm{~mm}$ & $12 \mathrm{~mm}$ \\
\hline 3. Salmonella paratyphi & $32 \mathrm{~mm}$ & - & $9 \mathrm{~mm}$ & - & - \\
\hline 4. Salmonella typhi & $28 \mathrm{~mm}$ & $7 \mathrm{~mm}$ & $11 \mathrm{~mm}$ & $7 \mathrm{~mm}$ & $8 \mathrm{~mm}$ \\
\hline 5. Vibrio parahemolyticus & $28 \mathrm{~mm}$ & $8 \mathrm{~mm}$ & $10 \mathrm{~mm}$ & $9 \mathrm{~mm}$ & $11 \mathrm{~mm}$ \\
\hline 6. Staphylococcus aureus & $28 \mathrm{~mm}$ & $9 \mathrm{~mm}$ & $9 \mathrm{~mm}$ & $8 \mathrm{~mm}$ & $9 \mathrm{~mm}$ \\
\hline 7. Escherichia coli & $29 \mathrm{~mm}$ & - & - & - & - \\
\hline 8. Shigella dysenteriae & $28 \mathrm{~mm}$ & $8 \mathrm{~mm}$ & $9 \mathrm{~mm}$ & $9 \mathrm{~mm}$ & $9 \mathrm{~mm}$ \\
\hline 9. Sarcina lutea & $29 \mathrm{~mm}$ & - & - & - & $8 \mathrm{~mm}$ \\
\hline 10. Bacillus megaterium & $31 \mathrm{~mm}$ & $8 \mathrm{~mm}$ & $8 \mathrm{~mm}$ & $9 \mathrm{~mm}$ & $9 \mathrm{~mm}$ \\
\hline
\end{tabular}

The inhibitory activities showed by the test samples were compared with that demonstrated by thestandard broad spectrum antibiotic Amikacin 10 $\mu$ l/disc. Amikacin showed a zone of inhibition against all microorganisms between $32 \mathrm{~mm}-28 \mathrm{~mm}$.

From this discussion we can say that the ethanolic extract of Ardisia colorata bark, Ardisia colorata leaves, were quite potent against some of the given gram positive bacterial strains and gram negative bacterial strains and hence has significant antimicrobial activity as determined by qualitative zone of inhibition by Diffusion Disc Technique/Methodology. Therefore further quantitative antimicrobial screening was extrapolated by alternative Minimum Inhibitory Concentration to deduce the exact numerical data. The MIC for $A$. colorata leaves for both strain 6 (Vibrio parahemolyticus) and strain 10(Bacillus subtilis) were found to be at its $3 \mathrm{mg} / \mathrm{ml}$ concentration. On the other hand no antibacterial activity was found for strain 4 (Salmonella typhi).

Table 3: MIC Results for Salmonella typhi, Vibrio parahemolyticus and Bacillus subtilis

\begin{tabular}{|c|c|c|c|c|c|c|c|c|c|}
\hline \multirow{3}{*}{$\begin{array}{c}\text { Specimen of } \\
\text { Research/Interest }\end{array}$} & \multirow{3}{*}{$\begin{array}{c}\text { Respective } \\
\text { strain of } \\
\text { microorganisms }\end{array}$} & \multicolumn{8}{|c|}{ Growth of Test Organisms } \\
\hline & & \multicolumn{3}{|c|}{ Differential Control Media } & \multicolumn{5}{|c|}{$\begin{array}{c}\text { Concentration of } \\
\text { Stock Solution } \\
(\mathrm{mg} / \mathrm{ml})\end{array}$} \\
\hline & & $\begin{array}{l}\text { Control } \\
1(C 1)\end{array}$ & $\begin{array}{l}\text { Control } \\
2(\mathrm{C} 2)\end{array}$ & $\begin{array}{l}\text { Control } \\
3 \text { (C3) }\end{array}$ & 1 & 2 & 3 & 4 & 5 \\
\hline $\begin{array}{l}\text { Ardisia colorata } \\
\text { leaves (ACL) }\end{array}$ & $\begin{array}{c}\text { ACL } 4 \\
\text { (Salmonella } \\
\text { typhi) }\end{array}$ & - & - & + & + & + & + & + & + \\
\hline
\end{tabular}




\begin{tabular}{|c|c|c|c|c|c|c|c|c|c|}
\hline \multirow{5}{*}{$\begin{array}{c}\text { Specimen of } \\
\text { Research/Interest }\end{array}$} & \multirow{3}{*}{$\begin{array}{c}\text { Respective } \\
\text { strain of } \\
\text { microorganisms }\end{array}$} & \multicolumn{8}{|c|}{ Growth of Test Organisms } \\
\hline & & \multicolumn{3}{|c|}{ Differential Control Media } & \multicolumn{5}{|c|}{$\begin{array}{c}\text { Concentration of } \\
\text { Stock Solution } \\
(\mathrm{mg} / \mathrm{ml})\end{array}$} \\
\hline & & $\begin{array}{l}\text { Control } \\
1 \text { (C1) }\end{array}$ & \begin{tabular}{|c} 
Control \\
2 (C2)
\end{tabular} & $\begin{array}{c}\text { Control } \\
3 \text { (C3) }\end{array}$ & 1 & 2 & 3 & 4 & 5 \\
\hline & $\begin{array}{c}\text { ACL } 6 \\
\text { (Vibrio } \\
\text { parahemolyticus) }\end{array}$ & - & - & + & + & + & - & - & - \\
\hline & $\begin{array}{c}\text { ACL } 10 \\
\text { (Bacillus subtilis) }\end{array}$ & - & - & + & + & + & - & - & - \\
\hline
\end{tabular}

[-ve=negative growth or positive antibacterial activity, $+v e=$ positive growth or negative antibacterial activity]

\section{Conclusion}

The present study indicated that the ethanol extracts of the Ardisia colorata leaves have got significant antimicrobial activity. It may be proposed that more study should be carried out using higher doses of the extracts concerned. If possible other potential pharmacological activities should be conducted such as anti-cancer or anti-psychotic activity. Hopefully this study will lead us to think whether or not Ardisia colorata can be used commercially as antimicrobial medicine or not.

\section{Acknowledgement}

We would like to attribute our triumphant success to complete the research to our respective teacher Dr. Rajib Bhattacherjee, Assistant Professor, Department of Pharmacy at North South University, who has been a constant support and inspiration for us to accomplish this work till the last second and made us believe that after all research is not only collecting and interpretation of data but rather constitutes lot of integrative thinking, research interest and aspiring knowledge and passion. We would like to show our gratitude to all of the staffs of the Department of Pharmacy, North South University, Bashundhara, Dhaka, Bangladesh.

\section{References}

1. Nair, R. and S. Chanda, 2006. Activity of some medicinal plants against certain pathogenic bacterial strains. Indian J. Pharmacol., 38: 142-144.

2. Nascimento, G.G.F., J. Locatelli, P.C. Freitas and G.L. Silva, 2000. Antibacterial activity of plant extracts and phytochemicals on antibiotic-resistant bacteria. Braz. J. Microbiol., 31: 247-256.

3. Akinmoladun, A.C., EO. Ibukun, E. A for EM. Obuotor and EO.Farombi, 2007. Phytochemical constituent and antioxidant activity of extract from the leaves of Ocimum gratissimum. Sci. Res. Essay, 2: 163-166.

4. M.Sumino, T. Sekine, N.Ruangrunski and F. Ikegami, 2001, Ardisiphenols A-C,Novel Antioxidants from the fruits of Ardisia colorata.

5. J.B.Harborne (eds.) 1998. Phytochemical Methods: A guide to modern techniques of plant analysis. 3rd ed. Chapman and Hall, London ISBN: 0-412-57270-2, 302. 
6. Haque, M., M.E. Haque and M.M. Rahman, 2008. "Antibacterial and cytotoxic activities of Capparis zeylanica Linn roots”, Ars Pharmaceutica 49, pp.31-37.

7. S.Sazada, A.Verma, A.A.Rather, F.Jabeen and M.K. Meghvansi 2009. Preliminary phytochemicals analysis of some important medicinal and aromatic plants. Adv. in Biol. Res., 3, 188-195.

8. Kanchanapee P., Ogawa H., Natori S.,Shoyakugaku Zashhi, 21, 68-69, (1967).

9. Bauer A.W., W.M. M. Kirby, J.C. Sherries and M. Tuck, 1966. "Antibiotic susceptibility testing by a standardized disc diffusion method", American Journal of Clinical Pathology 45pp. 493-496.

10.L.O. Tippet, L.D. Zeleznick and C.A Robb,1970. Modification of the Microtiter Technique for Antimicrobial Drug Susceptibility Testing,Applied Microbiology, p342-345.

11. Aguinaldo AM, Espeso El, Guevara BQ, Nonato MG 2005. Phytochemistry. In: Guevara BQ (ed.) A Guidebook to Plant Screening: Phytochemical and Biological. University of Santo Tomas, Manila, Philippines.

12. Moon YJ, Wang X, Morris ME 2006. Dietary flavonoids: Effects on xenobiotic and carcinogen metabolism. Toxicol. In vitro 20: 187-210. Mothana RA, Abdo SAA, Hasson S, Althawab FMN, Alaghbari SAZ.

13. Veitch NC 2007. Isoflavonoids of the Leguminosae. Nat. Prod. Rep. 24: 417-464.

14. Jiang $\mathrm{H}$, Zhan WQ, Liu X, Jiang SX 2008. Antioxidant activities of extracts and flavonoid compounds from Oxytropis falcate Bunge. Nat. Prod. Res. 22(18): 1650-1656.

15. Kim HP, Son KH, Chang HW, Kang SS 2004. Anti-inflammatory Plant Flavonoids and Cellular Action Mechanisms. J. Phamacol. Sci. 96:229-245.

16. Wu JH, Tung YT, Chien SC, Wang SY, Kuo YH, Shyur LF, Chang ST 2008. Effect of Phytocompounds from the Heart-wood of Acacia confusa on Inflammatory Mediator Production. J. Agric. Food Chem.56: 1567-1573. 